\title{
Stress-Induced Cocaine Seeking Requires a Beta-2 Adrenergic Receptor-Regulated Pathway from the Ventral Bed Nucleus of the Stria Terminalis That Regulates CRF Actions in the Ventral Tegmental Area
}

\author{
Oliver Vranjkovic, Paul J. Gasser, Clayton H. Gerndt, David A. Baker, and John R. Mantsch \\ Department of Biomedical Sciences, Marquette University, Milwaukee, Wisconsin 53201
}

\begin{abstract}
The ventral bed nucleus of the stria terminalis (vBNST) has been implicated in stress-induced cocaine use. Here we demonstrate that, in the vBNST, corticotropin releasing factor (CRF) is expressed in neurons that innervate the ventral tegmental area (VTA), a site where the CRF receptor antagonist antalarmin prevents the reinstatement of cocaine seeking by a stressor, intermittent footshock, following intravenous self-administration in rats. The vBNST receives dense noradrenergic innervation and expresses $\beta$ adrenergic receptors (ARs). Footshock-induced reinstatement was prevented by bilateral intra-vBNST injection of the $\beta$-2 AR antagonist, ICI-118,551, but not the $\beta-1 \mathrm{AR}$ antagonist, betaxolol. Moreover, bilateral intra-vBNST injection of the $\beta-2 \mathrm{AR}$ agonist, clenbuterol, but not the $\beta$-1 agonist, dobutamine, reinstated cocaine seeking, suggesting that activation of vBNST $\beta-2$ AR is both necessary for stress-induced reinstatement and sufficient to induce cocaine seeking. The contribution of a $\beta$-2 AR-regulated vBNST-to-VTA pathway that releases CRF was investigated using a disconnection approach. Injection of ICI-118,551 into the vBNST in one hemisphere and antalarmin into the VTA of the contralateral hemisphere prevented footshock-induced reinstatement, whereas ipsilateral manipulations failed to attenuate stressinduced cocaine seeking, suggesting that $\beta-2$ AR regulate vBNST efferents that release CRF into the VTA, activating CRF receptors, and promoting cocaine use. Last, reinstatement by clenbuterol delivered bilaterally into the vBNST was prevented by bilateral vBNST pretreatment with antalarmin, indicating that $\beta-2$ AR-mediated actions in the vBNST also require local CRF receptor activation. Understanding the processes through which stress induces cocaine seeking should guide the development of new treatments for addiction.
\end{abstract}

Key words: BNST; cocaine; CRF; relapse; stress; VTA

\section{Introduction}

In many cocaine addicts, relapse to drug use is triggered by the onset of craving in response to episodes of stress. Due to the uncontrollable and often unavoidable nature of stress, its contribution to relapse is particularly problematic when managing cocaine addiction.

Using rodent reinstatement models, preclinical researchers have begun to define the neurocircuitry that underlies stressinduced relapse. One prominent pathway that has been implicated consists of a dopaminergic projection from the ventral tegmental area (VTA) to the medial prefrontal cortex, where dopamine D1 receptor activation increases the activity of a glutamatergic pathway to the nucleus accumbens that is critical for cocaine seeking (Capriles et al., 2003; McFarland et al., 2004).

Received Feb. 17, 2014; revised July 29, 2014; accepted July 31, 2014

Author contributions: 0.V., D.A.B., and J.R.M. designed research; 0.V., C.H.G., and J.R.M. performed research; O.V., P.J.G., and J.R.M. analyzed data; 0.V. and J.R.M. wrote the paper.

This work was supported by National Institute on Drug Abuse Grant DA15758 to J.R.M.

The authors declare no competing financial interests.

Correspondence should be addressed to Dr John R. Mantsch, Department of Biomedical Sciences, Box 1881, Marquette University, Milwaukee, WI 53201-1881. E-mail: john.mantsch@marquette.edu.

DOI:10.1523/JNEUROSCI.0680-14.2014

Copyright $\odot 2014$ the authors $\quad 0270-6474 / 14 / 3412504-11 \$ 15.00 / 0$
During stress, the VTA is regulated by the neuropeptide corticotropin releasing factor (CRF; Wang et al., 2005), in part via CRF-R1 receptors (Blacktop et al., 2011), to evoke cocaine seeking.

The VTA receives inputs from brain regions involved in integration of the stress response, including those comprising the "extended amygdala": the nucleus accumbens shell, central amygdala, and bed nucleus of the stria terminalis (BNST; Phillipson, 1979). Among these structures, the BNST, which serves as an interface between stress and motivational/reward systems, appears to be particularly important for stress-induced cocaine seeking, in that its inactivation prevents stress-induced reinstatement in rodents (McFarland et al., 2004; Briand et al., 2010). A subgroup of neurons projecting from the BNST to the VTA express CRF (Rodaros et al., 2007) and therefore may be responsible for stress-induced increases in VTA CRF and CRF-dependent cocaine seeking. However, CRF projections to the VTA from the ventral BNST (vBNST), the subregion implicated in stressinduced cocaine seeking (McFarland et al., 2004), have not been described. The BNST, particularly the vBNST, receives dense noradrenergic innervation (Phelix et al., 1992) and expresses $\beta$ adrenergic receptors (ARs; Cecchi et al., 2007), which have been reported to regulate efferent projections (Nobis et al., 2011), in- 
cluding those that innervate the VTA (Dumont and Williams, 2004; Silberman et al., 2013). Both stress-induced reinstatement (Erb and Stewart, 1999; Erb et al., 2001) and noradrenergic regulation of BNST efferents to the VTA (Silberman et al., 2013) require BNST CRF receptor activation, suggesting that norepinephrine in the BNST promotes local CRF release, thereby activating a second CRF-releasing pathway to the VTA.

Considering the important role for noradrenergic signaling in stress-induced reinstatement in rodents (Erb et al., 2000; Mantsch et al., 2010) and craving in human cocaine-dependent populations (Jobes et al., 2011), AR regulation of a vBNST-to-VTA CRF-releasing pathway is a likely mechanism through which stress promotes cocaine seeking. We have found that $\beta$-2 AR activation is both necessary and sufficient for stress-induced reinstatement in mouse models (Vranjkovic et al., 2012). Moreover, it has been demonstrated that a mixture of $\beta$-AR antagonists, administered into the vBNST, prevents stressinduced reinstatement (Leri et al., 2002). In this study, we demonstrate direct CRF neuronal projections from the vBNST to the VTA and examine the relationship between stress-induced $\beta-2$ AR activation in the vBNST and CRF-R1 receptor-dependent actions in the VTA that lead to cocaine seeking.

\section{Materials and Methods}

\section{Subjects}

Male Sprague Dawley rats (Harlan Laboratories) 90-d-old at the time of delivery ( $325 \mathrm{~g}$ ) were used. Rats were housed singly in a temperatureand humidity-controlled, Association for Assessment and Accreditation of Laboratory Animal Care accredited facility under a $12 \mathrm{~h}$ light/dark cycle (lights off at 07:00 h) and had access to food and water at all times, except during the food training periods during which they were kept at $90 \%$ of their free-feeding body weight. All procedures were performed in accordance with the NIH Guide for the Care and Use of Laboratory Animals.

\section{Drugs}

Cocaine $\mathrm{HCl}$ was acquired from the National Institute on Drug Abuse through its drug supply program. The selective $\beta-1$ AR antagonist betaxolol $\mathrm{HCl}$, the selective $\beta-2 \mathrm{AR}$ antagonist (-)-(isopropylamino)-1-[(7methyl-4-indanyl)oxy] butan-2-ol (ICI-118,551) $\mathrm{HCl}$, the selective $\beta$-1 $\mathrm{AR}$ agonist dobutamine $\mathrm{HCl}$, the selective $\beta-2$ AR agonist clenbuterol, and the axonal transport inhibitor colchicine $\mathrm{HCl}$ were purchased from Sigma-Aldrich. Cocaine was dissolved in bacteriostatic saline. Other drugs were dissolved in sterile water. Colchicine was delivered intracerebroventricularly in a volume of $2 \mu \mathrm{l}$ over a $5 \mathrm{~min}$ period. Intracranial drug injections occurred in a volume of $0.2 \mu \mathrm{l} /$ side over a $1 \mathrm{~min}$ period.

\section{Catheter and cannula implantation}

For intravenous self-administration (SA) and reinstatement testing, rats were implanted with catheters into the jugular vein under ketamine $\mathrm{HCl}$ (100 mg/kg i.p.) and xylazine (2 mg/kg, i.p.) anesthesia, as described previously (Blacktop et al., 2011), along with $11 \mathrm{~mm}$ 26-gauge guide cannulae aimed at the vBNST $(0.6 \mathrm{~mm}$ posterior to bregma; $3.5 \mathrm{~mm}$ lateral to midline; $6.9 \mathrm{~mm}$ ventral to the skull surface at a $15^{\circ}$ angle), and/or the VTA ( $5.6 \mathrm{~mm}$ posterior to bregma; $2.2 \mathrm{~mm}$ lateral to midline; 6.9 ventral to the skull surface at a $12^{\circ}$ angle) for intracranial injections. The tips of the guide cannulae were aimed $0.5 \mathrm{~mm}$ above the target injection sites.

\section{Cocaine self-administration}

Following a 2 week recovery from surgery, rats were trained to selfadminister cocaine $(1.0 \mathrm{mg} / \mathrm{kg} / \mathrm{inf}$, i.v.) by pressing a response lever under an FR1 schedule in a computer-interfaced operant conditioning chamber (Med Associates) during daily $2 \mathrm{~h}$ sessions. During these sessions, the active (front) lever was extended into the chamber and the corresponding stimulus light was illuminated. Pressing this lever resulted in a cocaine infusion ( $200 \mu$ l over $5 \mathrm{~s})$, followed by a $25 \mathrm{~s}$ time-out period during which the stimulus light was extinguished but the lever remained extended. Responding on a second, inactive lever was recorded but had no programmed consequences. Once stable SA under the FR1 schedule was observed ( $>15$ infusions), the requirements for SA were gradually increased until rats displayed stable responding under ta FR4 schedule $(<10 \%$ variation from the mean over 3 sessions), at which time daily access was increased to $6 \mathrm{~h}$. Rat were permitted to self-administer daily under these conditions for 14 consecutive days after which they underwent extinction training.

\section{Extinction training and reinstatement testing}

Extinction sessions were identical to SA conditions except that (1) the sessions were $2 \mathrm{~h}$ in duration and (2) the cocaine solution was replaced with saline. Daily extinction training sessions were conducted until rats displayed $<15$ cocaine lever responses for consecutive sessions (range, $6-10 \mathrm{~d}$ ) at which time rats were tested for reinstatement. Reinstatement sessions were identical to extinction sessions except that they were preceded by exposure to shock and/or intracranial drug delivery. Shocks ( 0.5 $\mathrm{mA}, 0.5 \mathrm{~s}$ duration) were delivered on average every $40 \mathrm{~s}$ (range, $10-70 \mathrm{~s}$ ) through the grid floors of the chambers over a $15 \mathrm{~min}$ period that immediately preceded the $2 \mathrm{~h}$ reinstatement test session (Blacktop et al., 2011; Graf et al., 2011). During the shock session, the levers were retracted and the stimulus lights were off, but a houselight in the chamber was illuminated. Reinstatement was defined as an increase in cocaine lever responding relative to the prior extinction session. When rats were tested multiple times for reinstatement, test sessions were separated by additional extinction session and were required to display $<15$ cocaine lever responses before retesting.

\section{Effects on food-reinforced lever pressing}

In most cases where significant reductions in shock-induced reinstatement were observed, the effects of the same manipulations on lever pressing reinforced by food delivery ( $45 \mathrm{mg}$ sucrose-sweetened food pellets; BioServ) were also examined in separate rats to confirm that reduced reinstatement was not attributable to motor impairment that interfered with the ability of the rats to press the lever. Following surgical intracranial implantation of guide cannulae and recovery, these rats were maintained at $90 \%$ of their free-feeding body weights and trained to self-administer food pellets by pressing a lever under a FR4 schedule. Effects on food-reinforced responding were tested after stable patterns of lever pressing were observed $(<10 \%$ variation from the mean over 3 sessions).

\section{Histological confirmation of injection sites}

The accuracy of cannula implantation was confirmed postmortem in each rat after cardiac perfusion with $60 \mathrm{ml} 0.15 \% \mathrm{NaCl}$ followed by $60 \mathrm{ml}$ of $2.5 \%$ buffered neutral formalin under sodium pentobarbital anesthesia $(55 \mathrm{mg} / \mathrm{kg})$. Brains were removed and stored in $2.5 \%$ buffered formalin before vibratome sectioning $(40 \mu \mathrm{m})$, slide mounting, and staining with cresyl violet for examination using a light microscope. Rats with injection sites outside of the VTA or the vBNST were excluded from data analysis.

\section{Experiment 1: effects of intra-BNST $\beta$ AR antagonists on stress- induced reinstatement}

We initially examined the role of $\beta-1$ and $\beta-2$ AR activation in the vBNST in stress-induced reinstatement by testing rats for shock-induced reinstatement following bilateral intra-vBNST injection of the $\beta$-1 AR selective antagonist, betaxolol ( $1 \mathrm{nmol} / 307 \mathrm{ng}$ per side), the $\beta$-2 AR antagonist selective antagonist, ICI-118,551 ( $1 \mathrm{nmol} / 277 \mathrm{ng}$ per side) or vehicle (sterile water). Concentrations were selected based on selectivity for human $\beta$ receptor subtypes (Baker, 2005). Moreover, the antagonist concentrations were previously used to selectively target brain $\beta$ ARs (Delfs et al., 2000; Leri et al., 2002; Cecchi et al., 2007; LaLumiere et al., 2010). Rats received vBNST injections 15 min before shock. Nine total rats were used for this experiment. Five rats were tested for shockinduced reinstatement following pretreatment with vehicle, betaxolol, and ICI-118,551; two rats were tested following only vehicle and betaxolol; and two rats were tested for following only vehicle and ICI-118,551. 
An additional group of rats $(n=6)$ was tested for the effects of ICI118,551 and vehicle on food-reinforced lever pressing.

\section{Experiment 2: reinstatement by intra- $v B N S T$ injection of} $\beta$-AR agonists

To further examine the role of vBNST $\beta-1$ and $\beta$-2 ARs in stress-induced cocaine seeking, a separate group of rats was tested for the ability of bilateral intra-vBNST injection of the $\beta-1$ AR selective agonist dobutamine ( $1 \mathrm{nmol} / 301 \mathrm{ng}$ per side) or the $\beta$-2 AR selective agonist clenbuterol ( $36 \mathrm{pmol} / 10 \mathrm{ng}$ per side) to induce reinstatement. Concentrations were again chosen based on selectivity for human $\beta$ receptor subtypes (Baker, 2010). Further, the clenbuterol dose has been previously used to selectively target brain $\beta$-2 ARs (Roozendaal et al., 2008; LaLumiere et al., 2010). Ten total rats were used for this experiment. Seven rats were tested for reinstatement in response to dobutamine, clenbuterol, and vehicle. An additional three rats were tested only with clenbuterol and vehicle.

\section{Experiment 3: effect of VTA CRF receptor antagonism on} stress-induced reinstatement

To confirm our earlier finding that shock-induced reinstatement requires CRF receptor activation in the VTA (Blacktop et al., 2011), we also tested rats for the effects of intra-VTA pretreatment with the CRF-R1 receptor antagonist, antalarmin (Webster et al., 1996; $1.32 \mathrm{nmol} / 500$ ng/side). We (Blacktop et al., 2011) and others (Lowery-Gionta et al., 2012) have used this antalarmin dose to investigate CRF-R1 receptordependent contributions to behavior. Six rats were used for this experiment. Each of them was tested for the effects of both antalarmin and vehicle on shock-induced reinstatement

\section{Experiment 4: identification of CRF-positive neurons in the $\checkmark B N S T$ that project to the VTA}

Retrograde tracing using $C T b$. We used cholera toxin B subunit $(\mathrm{CTb})$ as a retrograde tracer to identify neurons in the vBNST with direct efferent projections to the VTA. Rats were anesthetized with ketamine and xylazine and placed in a stereotaxic frame. Heat-sterilized Hamilton syringes were used to pressure inject $0.2 \mu \mathrm{l}$ biotinylated CTb (List Biological Laboratories) unilaterally into the VTA over a $10 \mathrm{~min}$ period (posterior to bregma $-5.6 \mathrm{~mm}$, lateral $-2.6 \mathrm{~mm}$, ventral $-8.6 \mathrm{~mm}$; Paxinos and Watson, 2006). Syringes were left in place for $20 \mathrm{~min}$ after injections and slowly removed from the brain over a $10 \mathrm{~min}$ period.

Colchicine treatment. Because it has been reported that inhibition of axonal transport using pretreatment with the microtubule polymerization inhibitor colchicine is necessary for detection of CRFimmunoreactive cell bodies within the vBNST (Sakanaka et al., 1986) anesthetized rats received injections of colchicine $(1.25 \mu \mathrm{mol} / 500 \mu \mathrm{g}$ in 2 $\mu \mathrm{l}$ ) into a lateral ventricle (posterior to bregma $-1.0 \mathrm{~mm}$, lateral $1.4 \mathrm{~mm}$, ventral $-5.3 \mathrm{~mm}) 10 \mathrm{~d}$ after injection with $\mathrm{CTb}$, thus avoiding interference with retrograde transport of CTb.

Tissue collection and preparation. Twenty-four hours after the colchicine injections, rats were anesthetized with sodium pentobarbital (55 $\mathrm{mg} / \mathrm{kg}$, i.p.) and perfused transcardially with $30 \mathrm{ml}$ of $0.9 \% \mathrm{NaCl}$, followed by $60 \mathrm{ml}$ of cold $\left(4^{\circ} \mathrm{C}\right) 4 \%$ paraformaldehyde in $0.1 \mathrm{M}$ phosphate buffer, $\mathrm{pH}$ 7.0. Brains were quickly removed and immersed in fixative for $24 \mathrm{~h}$ at $4^{\circ} \mathrm{C}$. Brains were washed twice in $0.1 \mathrm{M}$ sodium phosphate buffer for $12 \mathrm{~h}$ each, after which they were cryoprotected in $30 \%$ sucrose in 0.1 $\mathrm{M}$-phosphate buffer for $3 \mathrm{~d}$ at $4^{\circ} \mathrm{C}$. Brains were rapidly frozen and serial coronal sections $(30 \mu \mathrm{m})$ were cut on a cryostat. Sections were stored at $-20^{\circ} \mathrm{C}$ until immunofluorescence procedures were conducted.

Fluorescence immunocytochemistry. Immunofluorescence for $\mathrm{CTb}$ and CRF was conducted on free-floating $30 \mu \mathrm{m}$ sections. Sections were rinsed three times for $10 \mathrm{~min}$ in $0.05 \mathrm{M} \mathrm{KPBS}$ and once for $10 \mathrm{~min}$ in $0.1 \mathrm{M}$ glycine in $0.05 \mathrm{KPBS}$, followed by blocking in 3\% normal donkey serum in $0.4 \%$ Triton KPBS for $20 \mathrm{~min}$. Sections were then incubated for $48 \mathrm{~h}$ at $4^{\circ} \mathrm{C}$ with rabbit anti-CRF (supplied by Dr Wylie Vale, The Salk Institute) diluted 1:8000 in 0.1\% Triton KPBS with 3\% normal donkey serum. Sections were then rinsed $3 \times 10 \mathrm{~min}$ in $0.05 \mathrm{M}$ KPBS, followed by incubation with an AlexaFluor 488-conjugated donkey anti-rabbit secondary antibody (Catalog \#A11008; 1:500; Life Technologies) in 0.05 M KPBS for $2 \mathrm{~h}$ at room temperature, and rinsed three times for $10 \mathrm{~min}$ in $0.05 \mathrm{M}$ KPBS. For detection of biotinylated $\mathrm{CTb}$, sections were incubated for
$24 \mathrm{~h}$ at $4^{\circ} \mathrm{C}$ in goat anti-biotin polyclonal antibody (Catalog \# SP 3000; Vector Laboratories) diluted 1:30,000 in 0.1\% Triton KPBS and 3\% normal donkey serum. After rinsing, sections were incubated $2 \mathrm{~h}$ with AlexaFluor 598-conjugated donkey anti-goat IgG (Catalog \#A-110581; 1:500; Life Technologies) and washed three times for $10 \mathrm{~min}$ in $0.05 \mathrm{M}$ KPBS. Sections were briefly rinsed in distilled water and mounted onto gelcoated SuperFrost Plus slides and coverslipped using Vectashield mounting medium with DAPI (Catalog \#H-1200; Vector Laboratories). Photomicrographs were acquired using a Retiga 2000R digital camera (QImaging) on a Nikon 80i microscope using NIS Elements software (Nikon Instruments).

\section{Experiment 5: effects of $v B N S T$ and VTA disconnection on stress-} induced cocaine seeking

A disconnection approach was used to determine whether a $\beta$ 2-AR activated, CRF-dependent pathway between the vBNST and the VTA is required for stress-induced cocaine seeking. At the time of catheterization, separate groups of rats were implanted with two cannulae aimed unilaterally at the vBNST and VTA in either the contralateral or the ipsilateral hemisphere(s) of the brain. The effect of pathway disconnection was examined in six rats by injection of the $\beta-2$ AR antagonist ICI $118,551(1 \mathrm{nmol} / 277 \mathrm{ng})$ into the vBNST in one hemisphere and the CRF-R1 receptor antagonist antalarmin $(1.32 \mathrm{nmol} / 500 \mathrm{ng})$ into the VTA of the other before testing for shock-induced reinstatement. For comparison, the same rats were tested for shock-induced reinstatement following injection of vehicle into each region. As a control to ensure that reductions in reinstatement were attributable to disconnection, a second groups of rats $(n=7)$ received a unilateral injection of ICI 118,551 into the vBNST in one hemisphere and a unilateral injection of antalarmin into the VTA in the same hemisphere before testing for shock-induced reinstatement. These rats were also tested for the effects of ipsilateral vehicle injections. For this experiment, the hemispheres into which cannulae were implanted were randomized across rats in each group such that in the contralateral treatment group, half of the rats received ICI 118,551 injections into the left vBNST and antalarmin injections into the right VTA, whereas the other half received ICI 118,551 injections into the right vBNST and antalarmin injections into the left VTA. Likewise, half of the rats in the ipsilateral treatment group received drug injections into sites in the right hemisphere, whereas the remaining rats received injections into sites in the left hemisphere. To examine the potential contribution of nonspecific behavioral suppression to the effects on reinstatement, an addition group of rats $(n=6)$ was tested for the effects of contralateral drug and vehicle injections on food-reinforced lever pressing.

\section{Experiment 6: role of $v B N S T C R F-R 1$ receptors in cocaine seeking} induced by $v B N S T \beta-2$ AR activation

It has been reported that CRF-R1 antagonist injections directly into the vBNST can also block stress-induced cocaine seeking (Erb and Stewart, 1999; Erb et al., 2001). To determine whether $\beta$-2 ARs in the vBNST regulate efferent pathways to the VTA to produce cocaine seeking via a mechanism that also involves local CRF actions, we tested for the ability of intra-BNST pretreatment with antalarmin to block reinstatement in response to local delivery of the beta $2 \mathrm{AR}$ agonist clenbuterol. Reinstatement in response to bilateral intra-BNST delivery of clenbuterol (36 $\mathrm{pmol} / 10 \mathrm{ng}$ per side) was examined following bilateral intra-BNST pretreatment with antalarmin $(1.32 \mathrm{nmol} / 500 \mathrm{ng} /$ side $)$ or vehicle $(10 \mathrm{~min}$ pretreatment) in counterbalanced sequence in six rats. To test the hypothesis that CRF-R1 receptor activation in the vBNST is downstream from $\beta$-2 AR activation in the sequence of events that mediate stress-induced cocaine seeking, a separate group of six rats was tested for reinstatement in response to bilateral intra-vBNST CRF ( $63 \mathrm{pmol} / 300 \mathrm{ng} / \mathrm{side}$; Erb and Stewart, 1999) following bilateral intra-vBNST pretreatment with the selective $\beta$-2 AR antagonist, ICI-118,551 ( $1 \mathrm{nmol} / 277 \mathrm{ng}$ per side) or vehicle (10 min pretreatment).

\section{Statistical analyses}

Statistical analyses were conducted using Predictive Analytics SoftWare statistics software (SPSS). Statistical significance was determined using ANOVA followed, when appropriate, by further analyses of main effects using ANOVA and/or post hoc testing using Bonferroni-corrected $t$ tests. 
Table 1. Cocaine SA and extinction

\begin{tabular}{|c|c|c|c|c|}
\hline \multirow[b]{2}{*}{ Experiment no. $(n)$} & \multicolumn{2}{|l|}{ Cocaine SA } & \multicolumn{2}{|l|}{ Extinction } \\
\hline & SA day 1 & SA day 14 & First Ext & Last Ext \\
\hline $1(9)$ & $77.22 \pm 7.71$ & $92.78 \pm 8.19$ & $66.33 \pm 11.50$ & $9.89 \pm 2.35$ \\
\hline $2(10)$ & $68.57 \pm 8.36$ & $89.38 \pm 7.07$ & $104.20 \pm 24.21$ & $9.70 \pm 1.14$ \\
\hline $3(6)$ & $75.10 \pm 5.86$ & $90.21 \pm 7.26$ & $70.20 \pm 29.14$ & $11.60 \pm 1.47$ \\
\hline $5(13)$ & $71.82 \pm 4.73$ & $85.74 \pm 4.01$ & $68.09 \pm 12.83$ & $12.00 \pm 2.39$ \\
\hline $6(12)$ & $74.00 \pm 4.82$ & $82.00 \pm 3.44$ & $129.62 \pm 16.09$ & $8.38 \pm 1.21$ \\
\hline
\end{tabular}

Data represent cocaine $S A$ (infusions $/ 6 \mathrm{~h}$ session $\pm S E$ ) on days 1 and 14 of $S A$ testing and cocaine lever responding (responses $/ 2 \mathrm{~h}$ session $\pm \mathrm{SE}$ ) on the first day of extinction training (First Ext) and the last day of extinction training prior to reinstatement testing (Last Ext) in rats from each of the reinstatement experiments.

\section{Results}

Cocaine SA and extinction in rats used for the various reinstatement experiments are shown in Table 1 and did not differ across experiments. In general, each group of rats displayed escalation, as previously demonstrated under these conditions, and showed reduced cocaine seeking across extinction testing, which consisted of an average of $8.24( \pm 0.28)$ sessions before extinction criteria were met. The injection sites for rats used for each experiment are depicted in Figure 1. A total of 11 rats were excluded from analyses due to cannula misplacement. In all cases, drug effects were not observed with inaccurate injections.

\section{Experiment 1: effects of intra-BNST $\beta$ AR antagonists on stress-induced reinstatement}

The effect of bilateral intra-vBNST injection of the $\beta$ - 1 AR antagonist betaxolol ( $1 \mathrm{nmol} / 307 \mathrm{ng}$ per side) on shock-induced reinstatement was examined in seven rats and is shown in Figure $2 A$. Two-way repeated measures (reinstatement $\times$ betaxolol) ANOVA showed a significant overall reinstatement effect $\left(F_{(1,6)}\right.$ $=65.437 ; p<0.001$ ) but no main effect of betaxolol pretreatment or interaction between betaxolol treatment and reinstatement. Shock produced robust reinstatement regardless of whether rats were pretreated with betaxolol or vehicle. The effects of bilateral intra-vBNST injection of the $\beta$-2 AR antagonist ICI118,551 ( $1 \mathrm{nmol} / 277 \mathrm{ng}$ per side) pretreatment on shock-induced reinstatement were also examined in seven rats and are shown in Figure $2 B$. Two-way repeated-measures ANOVA showed a significant reinstatement effect $\left(F_{(1,6)}=52.475 ; p<0.001\right)$ and a significant main effect of ICI-118,551 pretreatment $\left(F_{(1,6)}=\right.$ $10.224 ; p<0.05)$, as well as a significant reinstatement $\times$ ICI118,551 pretreatment interaction $\left(F_{(1,6)}=20.213 ; p<0.01\right)$. Shock reinstated cocaine seeking in vehicle but not ICI-118,551 pretreated rats ( $p<0.01$ vs extinction; Ext) and reinstatement was reduced in ICI-118,551 pretreated versus vehicle pretreated rats $(p<0.01)$. To assess potential motor impairment resulting from intra-vBNST ICI-118,551 delivery that may have nonspecifically interfered with reinstatement responding, a separate group of six rats was tested for effects of intra-vBNST ICI-118,551 on sucrose pellet-reinforced responding. ICI-118,551 pretreatment failed to alter lever pressing under these conditions (Fig. $2 C)$. In three of the rats that were tested, guide cannulae were misplaced such that they received injections into areas that comprise the dorsal BNST. Notably, in these rats, shock-induced reinstatement was observed in both vehicle-pretreated (Ext: $8.67 \pm$ 1.76 responses vs shock: $32.33 \pm 2.03)$ and ICI-118,551pretreated (Ext: $12.67 \pm 1.76$ responses vs shock: $28.33 \pm 4.81$ ) rats. Effects of shock were specific to the previously active lever as shock failed to increase responding on a previously inactive lever in vehicle-pretreated rats (Ext: $1.37 \pm 0.51$ responses vs shock: $1.02 \pm 0.44)$. Neither betaxolol nor ICI-118,551 affected inactive lever responding during reinstatement testing (vehicle: $1.02 \pm$ 0.44 responses; betaxolol: $1.00 \pm 0.33$; ICI-118,551: $0.75 \pm 0.31$ ).

\section{Experiment 2: reinstatement by intra- $v B N S T$ injection of}

$\beta$-AR agonists

Following SA and extinction, bilateral intra-vBNST delivery of clenbuterol (36 pmol/10 ng per side) but not dobutamine (1 nmol/ 301 ng per side), reinstated cocaine seeking (Fig. 3). A paired $t$ test showed that, compared with vehicle, pretreatment with clenbuterol significantly increased previously active lever pressing $\left(t_{(9)}=11.156 ; p<0.001\right)$. Neither dobutamine $(0.88 \pm$ 0.22 responses $)$ nor clenbuterol $(0.83 \pm 0.55$ responses $)$ increased responding on a previously inactive lever relative to vehicle pretreatment $(0.63 \pm 0.18)$ responses. Guide cannulae were misplaced in three rats such that they received injections into sites within the dorsal BNST. In contrast to rats that received intravBNST injections, neither clenbuterol (Ext: $8.67 \pm 1.99$ vs clenbuterol: $5.33 \pm 5.95)$ nor dobutamine (Ext: $10.00 \pm 2.07$ vs dobutamine: $9.33 \pm 7.60$ ) produced reinstatement in these rats.

\section{Experiment 3: effect of VTA CRF receptor antagonism on} stress-induced reinstatement

As previously reported (Blacktop et al., 2011), bilateral injection of the CRF-R1 receptor selective antagonist, antalarmin (1.32 nmol/500 ng per side) into the VTA prevented reinstatement. The effect of bilateral intra-VTA antalarmin pretreatment on shock-induced reinstatement was examined in six rats as shown in Figure 4. Two-way repeated-measures ANOVA showed a significant reinstatement effect $\left(F_{(1,5)}=12.971 ; p<0.05\right)$ and a significant main effect of antalarmin pretreatment $\left(F_{(1,5)}=\right.$ 9.175; $p<0.05)$, as well as a significant reinstatement $\times$ antalarmin pretreatment interaction $\left(F_{(1,5)}=8.461 ; p<0.05\right)$. As previously reported, shock reinstated cocaine seeking in vehicle but not antalarmin pretreated rats $(p<0.05$ vs Ext) and reinstatement was reduced in antalarmin pretreated versus vehicle pretreated rats $(p<0.05)$. As we have already demonstrated that intra-VTA antalarmin delivery does not alter food-reinforced lever pressing (Blacktop et al., 2011), we did not test for these effects in this study. In two of the rats that were tested, guide cannulae were misplaced such that they received injections outside of the VTA. Notably, in these rats, shock-induced reinstatement was observed in both vehicle-pretreated (Ext: 13 and 12 responses vs shock: 35 and 29 responses) and antalarminpretreated (Ext: 5 and 12 responses vs shock: 39 and 41 responses) rats. Effects of shock were specific to the previously active lever as shock failed to increase responding on a previously inactive lever in vehicle-pretreated rats (Ext: $1.12 \pm 0.29$ responses vs shock: $0.89 \pm 0.65)$. Antalarmin did not affect inactive lever responding during reinstatement testing (vehicle: $0.89 \pm 0.65$ responses; antalarmin: $0.81 \pm 0.52)$.

Experiment 4: identification of CRF-positive neurons in the $\checkmark B N S T$ that project to the VTA

To determine whether CRF-positive neurons within the vBNST project to the VTA, we injected CTb unilaterally into the VTA and looked for the presence of CTb/CRF double-labeled perikarya in the vBNST in four rats. Representative photomicrographs from one rat are shown in Figure 5. CTb-immunoreactive (CTb-ir) perikarya were observed in the vBNST ipsilateral, to the VTA injection site (average of $45 \mathrm{CTb}$-ir perikarya/ipsilateral vBNST). By contrast, and consistent with a previous report (Dong and Swanson, 2006), CTb immunoreactivity in the vBNST contralateral to the VTA injection site was minimal (average of four immunoreactive cells/contralateral vBNST). CRF- 


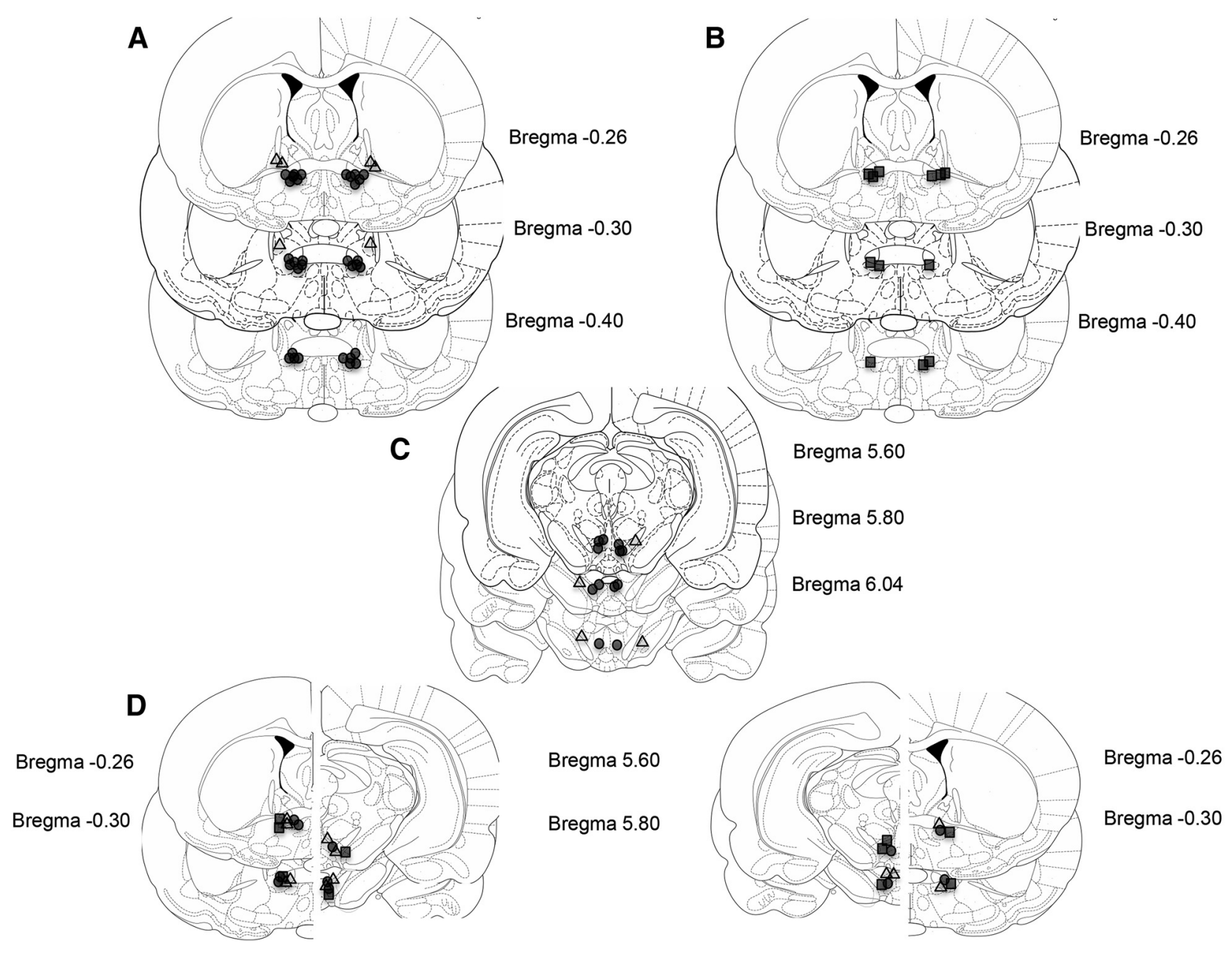

Figure 1. Intracranial injection sites. Representative atlas diagrams (Paxinos and Watson, 2006) of injection sites within the vBNST and the VTA. A, Rats from Experiments 1, 2 and 5; vBNST hits are depicted as circles and misses as triangles. B, Food control rats for Experiment 1; hits are depicted as squares and misses as triangles. C, Rats from Experiment 3; VTA hits are depicted as circles and misses as triangles. $\boldsymbol{D}$, Rats used for the Experiment 4; contralateral hits are depicted as circles, ipsilateral hits are depicted as squares and food-controls are depicted as triangles.
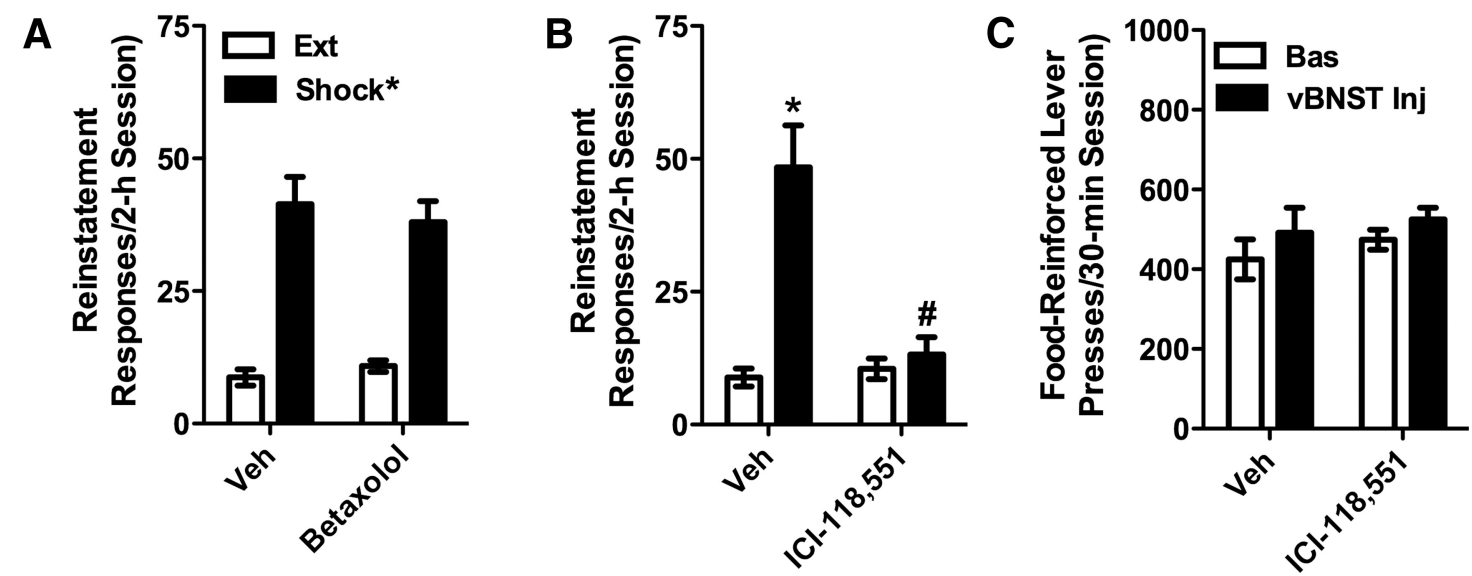

Figure 2. Footshock-induced reinstatement of cocaine seeking is blocked by intra-vBNST injection of the $\beta$-2 AR antagonist, ICI-118,551, but not the $\beta$-1 AR antagonist, betaxolol. Data represent the effects of bilateral intra-VBNST injections of betaxolol ( $1 \mathrm{nmol} / 307 \mathrm{ng}$ per side; $\boldsymbol{A} ; n=7)$ or ICl-118,551 ( $1 \mathrm{nmol} / 277 \mathrm{ng}$ per side; $\boldsymbol{B} ; n=7$ ) or vehicle on reinstatement (responses/2 hsession \pm SE) by electric footshock. Significant reinstatement was observed following intra-vBNST pretreatment with vehicle or betaxolol ( ${ }^{*} p<0.05$ vs Ext), but not ICl-118,551. Likewise, responding following ICl-118,551, but not betaxolol, was significantly reduced compared with vehicle pretreatment ( ${ }^{\#} p<0.05$ vs vehicle). By contrast, intra-vBNST ICI-118,551 failed to altered food-reinforced lever pressing $(\boldsymbol{C} ; n=6$ ).

like-immunoreactive (CRF-ir) perikarya and fibers were observed in the vBNST (Fig. 5). Under higher-magnification, three cell types were observed in the vBNST: CTb-ir/CRFimmunonegative, CTB-ir/CRF-ir, and CTb-immunonegative/
CRF-ir cells. Notably, most CRF-positive cells in the ipsilateral vBNST were also CTb-immunoreactive $(\sim 80 \%)$. By contrast, dual-labeled CRF- and CTb-positive cells were not observed in the contralateral vBNST. 


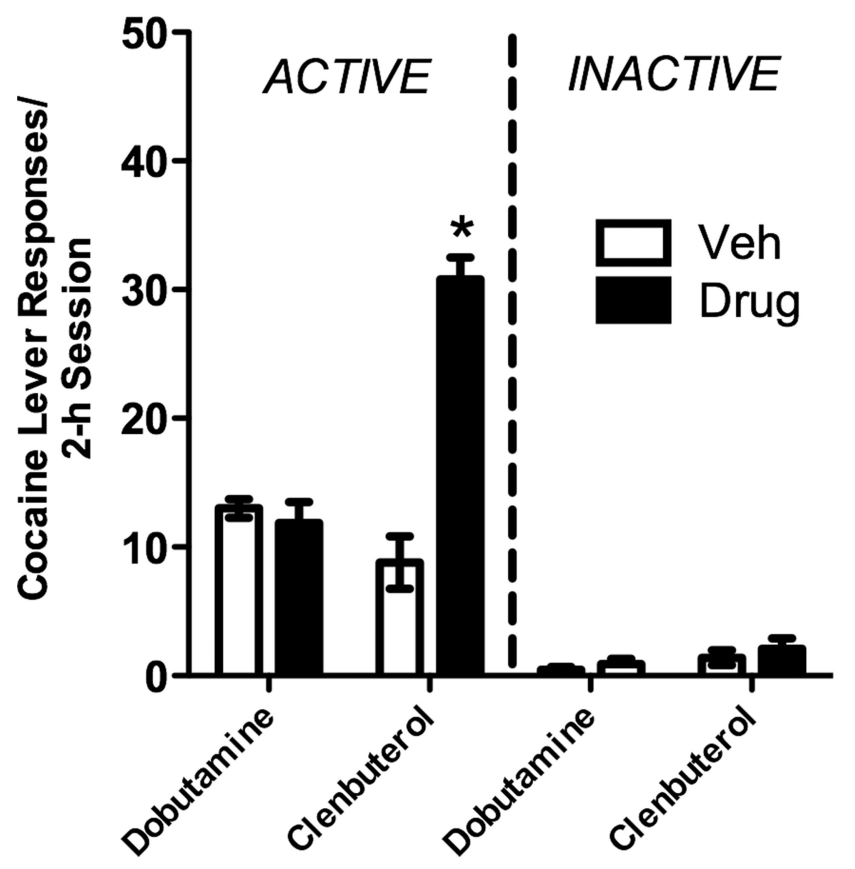

Figure 3. Reinstatement of extinguished cocaine seeking by bilateral injection of the $\beta-2 A R$ selective agonist, clenbuterol, but not the $\beta-1$ AR selective agonist, dobutamine, into the vBNST. Data represent responding on the cocaine lever (responses $/ 2 \mathrm{~h}$ session $\pm \mathrm{SE}$; active) or a previously inactive lever. Intra-VBNST clenbuterol ( $36 \mathrm{pmol} / 10 \mathrm{ng}$ per side; $n=10)$, but not dobutamine ( $1 \mathrm{nmol} / 301 \mathrm{ng}$ per side; $n=7$ ) reinstated extinguished cocaine seeking ${ }^{*} p<$ 0.05 vs vehicle). Neither dobutamine nor clenbuterol increased "inactive" lever responding.

Experiment 5: effects of $v B N S T$ and VTA disconnection on stressinduced cocaine seeking

To determine the role of a $\beta-2 \mathrm{AR}$ regulated pathway originating in the vBNST that releases CRF into the VTA in stress-induced cocaine seeking, we used a disconnection approach in which we delivered ICI-118,551 ( $1 \mathrm{nmol} / 277 \mathrm{ng})$ into the vBNST of one hemisphere and antalarmin $(1.32 \mathrm{nmol} / 500 \mathrm{ng})$ into the contralateral VTA ( $n=6$ rats). To confirm that any effect on reinstatement was attributable to pathway disconnection, a second group of rats $(n=5)$ received ICI-118,551 into the vBNST of one hemisphere and antalarmin into the ipsilateral VTA. Contralateral but not ipsilateral antagonist delivery prevented shockinduced reinstatement (Fig. 6A), suggesting that, during stress, $\beta-2 \mathrm{AR}$ in the vBNST regulate one or more pathways that release CRF into the VTA to induce cocaine seeking. A three-way ANOVA showed a significant interaction between reinstatement test condition (shock vs extinction; repeated measure), antagonist pretreatment (ICI-118,551/antalarmin vs vehicle/vehicle treatment; repeated measure), and injection site (contralateral vs ipsilateral; between-subjects; $\left.F_{(1,9)}=7.169 ; p<0.05\right)$. Further analysis revealed a significant interaction between antagonist treatment and shock-induced reinstatement only in rats that received contralateral antagonist injections $\left(F_{(1,5)}=25.851 ; p<\right.$ $0.01)$. Post hoc testing showed that significant shock-induced reinstatement was observed following vBNST/VTA vehicle (contralaterally or ipsilaterally) and following ipsilateral intra-vBNST ICI-118,551 and intra-VTA antalarmin pretreatments $(p<0.05$ for each comparison) but not following contralateral antagonist delivery. Furthermore, shock-induced reinstatement was significantly reduced following contralateral antagonist injections relative to either vehicle pretreatment or ipsilateral antagonist delivery ( $p<0.05$ for each comparison). To assess potential motor impairment resulting from the disconnection approach

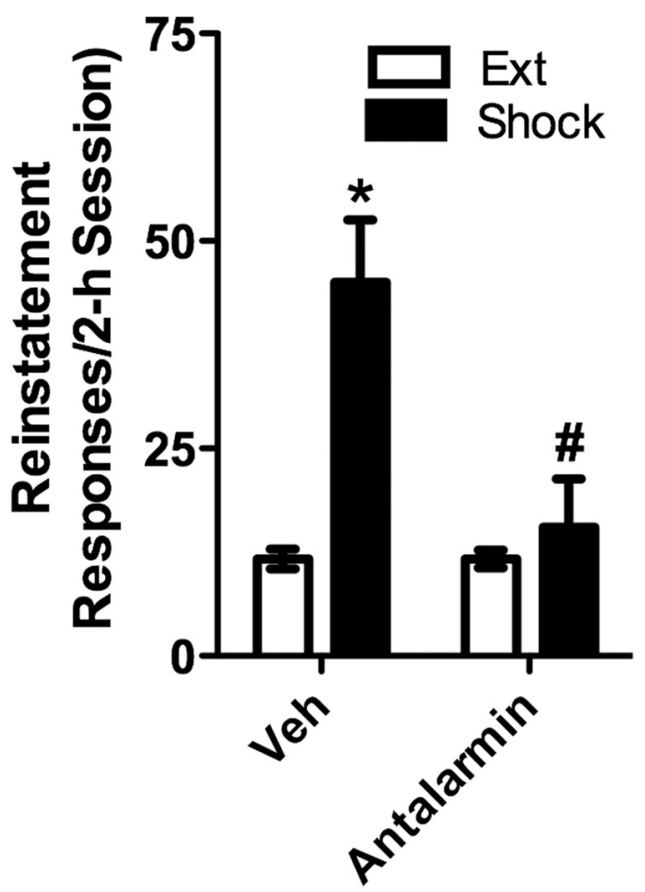

Figure 4. Bilateral injection of the CRF receptor antagonist, antalarmin, into the VTA prevents shock-induced reinstatement of cocaine seeking. Data represent the effects of bilateral intra-VBNST delivery of antalarmin ( $1.32 \mathrm{nmol} / 500 \mathrm{ng}$ per side; Fig. $2 A ; n=6)$ or vehicle on reinstatement (responses $/ 2 \mathrm{~h}$ session $\pm \mathrm{SE}$ ) following electric footshock. Significant reinstatement was observed after intra-vBNST pretreatment with vehicle ( ${ }^{*} p<0.05$ vs Ext) but not antalarmin. Likewise, responding following antalarmin was significantly reduced compared with vehicle pretreatment $\left({ }^{\#} p<0.05\right)$.

that may have nonspecifically interfered with reinstatement responding, a separate group of six rats were tested for effects on sucrose pellet-reinforced responding. Contralateral intra-vBNST ICI-118,551 and intra-VTA antalarmin delivery failed to alter lever pressing under these conditions (Fig. 6B). Effects of shock were specific to the previously active lever as shock failed to increase responding on a previously inactive lever in vehicle/ vehicle-pretreated rats (Ext: $0.88 \pm 0.35$ responses vs shock: $1.11 \pm 0.27)$. Neither ipsilateral nor contralateral manipulations affected inactive lever responding during reinstatement testing (vehicle/vehicle: $1.11 \pm 0.27$ responses; ipsilateral: $0.97 \pm 0.66$; contralateral: $0.93 \pm 0.66)$.

Experiment 6: role of $v B N S T$ CRF-R1 receptors in cocaine seeking induced by $v B N S T \beta-2$ AR activation

Because it has been reported that CRF receptors in the BNST are also required for stress-induced cocaine seeking (Erb and Stewart, 1999; Erb et al., 2001), and because BNST $\beta$ ARs have been proposed to modulate efferent projections to the VTA via regulation of local CRF actions (Silberman et al., 2013), we hypothesized that reinstatement induced by vBNST $\beta$-2 AR activation requires local CRF receptor activation. To test this hypothesis we delivered antalarmin $(1.32 \mathrm{nmol} / 500 \mathrm{ng}$ per side) bilaterally into the vBNST before bilateral vBNST injection of clenbuterol (36 pmol/10 ng per side). As shown in Figure 7, intra-vBNST antalarmin delivery prevented intra-vBNST clenbuterol-induced cocaine seeking $(n=7)$. Two-way repeated-measures ANOVA showed a significant reinstatement effect $\left(F_{(1,6)}=25.910 ; p<\right.$ $0.01)$ and a significant main effect of antalarmin pretreatment $\left(F_{(1,6)}=29.883 ; p<0.01\right)$, as well as a significant reinstatement $\times$ antalarmin pretreatment interaction $\left(F_{(1,6)}=35.968\right.$; $p<0.01)$. Clenbuterol reinstated cocaine seeking in vehicle but not antalarmin-pretreated rats ( $p<0.01 \mathrm{vs} \mathrm{Ext)}$ and reinstate- 
ment was reduced in antalarmin- versus vehicle-pretreated rats $(p<0.01)$. By contrast, bilateral intra-vBNST pretreatment with the $\beta-2 \mathrm{AR}$ antagonist, ICI118,551 ( $1 \mathrm{nmol} / 277 \mathrm{ng}$ per side) failed to attenuate reinstatement in response to intra-vBNST CRF delivery (63 pmol/300 ng per side). Two-way repeated-measures ANOVA showed an overall effect of CRF $\left(F_{(1,5)}=46.925\right)$ but no overall effect of ICI-118,551 pretreatment or no CRF $\times$ ICI-118,551 interaction. Altogether, these findings indicate that CRF receptor activation is likely downstream from $\beta-2 \mathrm{AR}$ activation in the sequence of events responsible for stress-induced reinstatement. Effects of intra-BNST clenbuterol $(2.14 \pm 0.67$ responses vs $1.38 \pm 0.73$ responses during extinction) and CRF $(0.66 \pm 0.42$ vs $0.00 \pm 0.00$ responses during extinction) on previously inactive lever responding were not observed. Likewise, neither intra-BNST antalarmin (antalarmin/clenbuterol: $1.16 \pm 0.16 \mathrm{re}-$ sponses) nor intra-BNST ICI-118,551 (ICI/CRF: $2.5 \pm 1.93$ responses) significantly altered inactive lever pressing during reinstatement.

\section{Discussion}

Our results extend earlier findings that the reinstatement of cocaine seeking by a stressor, electric footshock, requires CRF actions in the VTA (Wang et al., 2005; Blacktop et al., 2011) and vBNST $\beta$ AR activation (Leri et al., 2002) by showing that vBNST $\beta-2$ AR activation is both necessary and sufficient for stress-induced reinstatement. Moreover, using a disconnection approach in which we block $\beta-2$ ARs in the vBNST of one hemisphere and VTA CRF-R1 receptors in the contralateral hemisphere, we demonstrate that vBNST $\beta$-2 ARs regulate a CRF-releasing pathway to the VTA that is necessary for stress-induced cocaine seeking. As VTA $\mathrm{CTb}$ delivery labels CRF-positive cells in the ipsilateral vBNST, it is likely that this pathway consists (at least partly) of vBNST CRF neurons that project directly to the VTA. Consistent with reports that CRF actions in the BNST are required for stressor-induced cocaine seeking (Erb and Stewart, 1999; Erb et al., 2001), we demonstrate that vBNST CRF-R1 activation is necessary for reinstatement induced by local delivery of the $\beta-2 \mathrm{AR}$ agonist, clenbuterol, suggesting that $\beta-2 \mathrm{AR}-$ mediated activation of this BNST-to-VTA pathway also requires local CRF receptor activation.

Findings from laboratory studies in human cocaine addicts (Jobes et al., 2011) and preclinical experiments in rodents (Erb et al., 2000; Mantsch et al., 2010) point to a role for noradrenergic signaling in the stress-induced relapse to cocaine use. Specifically, our studies in mice suggest that $\beta-2$ ARs are critical for stressinduced cocaine seeking (Vranjkovic et al., 2012). As a target for ascending noradrenergic projections (Ricardo and Koh, 1978;
Weller and Smith, 1982; Woulfe et al., 1990) and a key site for integration of stress and reward networks (Flavin and Winder, 2013; Stamatakis et al., 2014), the BNST is a likely location at which stress-induced increases in norepinephrine regulate drug use. Although shock-induced increases in norepinephrine have not been reported, a variety of distinct stressors, including immobilization (Pacak et al., 1995), visceral pain (Deyama et al., 2009), and exposure to a shock-conditioned stimulus (Onaka and Yagi, 1998), fox odor (Fendt et al., 2005), or an aversive tastant (Park et al., 2012), have been demonstrated to increase noradrenergic neurotransmission in the BNST. In particular, the vBNST receives very dense noradrenergic innervation (Woulfe et al., 1988; Georges and Aston-Jones, 2001; Egli et al., 2005). Moreover, delivery of a mixture of $\beta-1$ and $\beta-2$ AR antagonists into the vBNST has been reported to prevent shock-induced reinstatement in rats (Leri et al., 2002). Our data extend these findings by demonstrating that $\beta-2$ but not $\beta-1$ AR activa- 
A
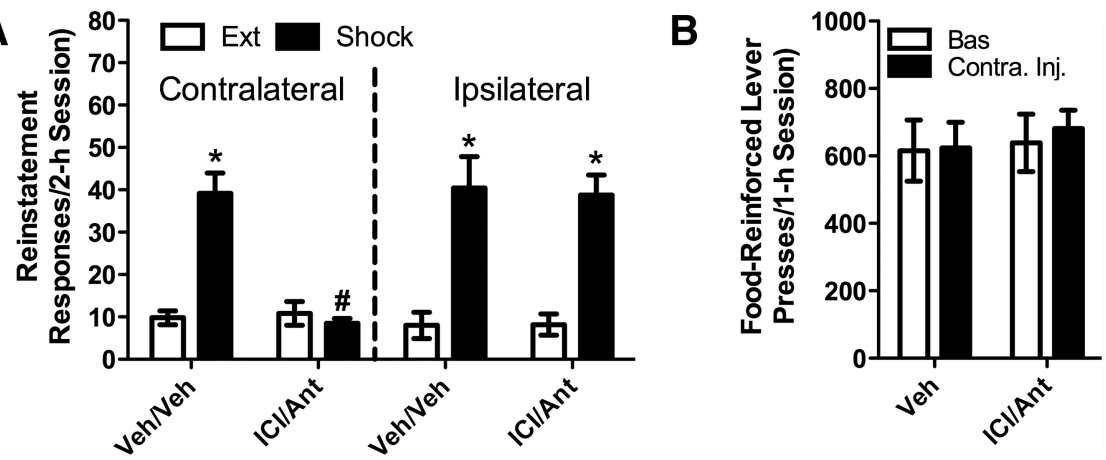

Figure 6. Disconnection of a $\beta$-2 AR-regulated vBNST-to-VTA CRF-releasing pathway prevents stress-induced cocaine seeking To determine the role of a $\beta-2$ AR regulated pathway originating in the vBNST that releases CRF into the VTA in stress-induced cocaine seeking, we used a disconnection approach in which we delivered ICl-118,551 into the vBNST of one hemisphere and antalarmin into the contralateral VTA ( $n=6$ rats) and tested for shock-induced cocaine seeking. To confirm that any effect on reinstatement was attributable to pathway disconnection, a second group of rats $(n=5)$ received an ICl-118,551 injection into the vBNST of one hemisphere and an antalarmin injection into the ipsilateral VTA. Significant shock-induced reinstatement was observed following vBNST/VTA vehicle (contralaterally or ipsilaterally) and following ipsilateral intra-vBNST ICl-118,551/intra-VTA antalarmin pretreatment ( ${ }^{*} p<0.05$ vs Ext) but not following contralateral antagonist delivery $(\boldsymbol{A})$. Furthermore, shock-induced reinstatement was significantly reduced following contralateral antagonist injections relative to either vehicle pretreatment or ipsilateral antagonist delivery ( ${ }^{\#} p<0.05$ for each comparison). By contrast, contralateral antagonist injections failed to altered food-reinforced lever pressing $(\boldsymbol{B} ; n=6)$.

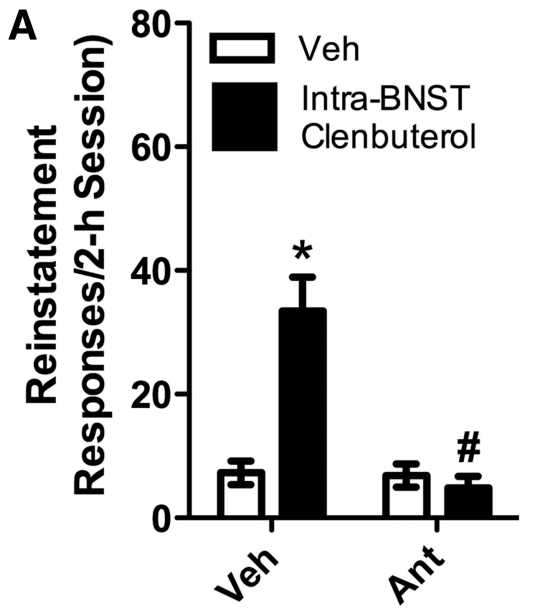

Intra-BNST pretreatment

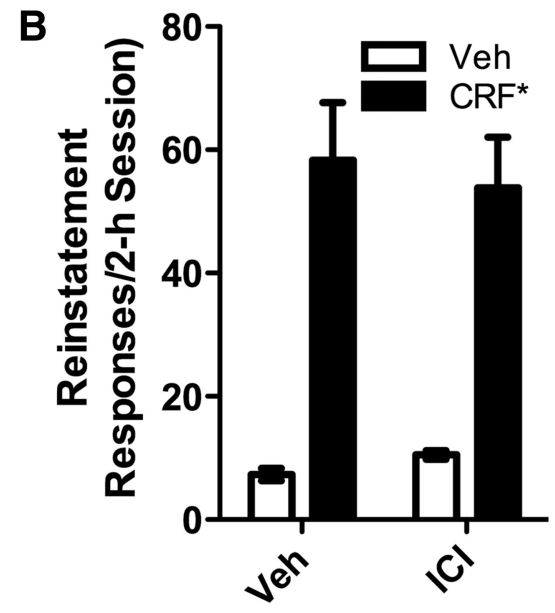

Intra-BNST pretreatment
Figure 7. Reinstatement of cocaine seeking by intra-vBNST clenbuterol injection requires activation of vBNST CRF-R1 receptors. Data represent the effects of $A$ : bilateral intra-vBNST pretreatment with antalarmin $(1.32 \mathrm{nmol} / 500 \mathrm{ng}$ per side) or vehicle on reinstatement (responses $/ 2 \mathrm{~h}$ session $\pm \mathrm{SE}$ ) in response to bilateral intra-vBNST clenbuterol injection ( $36 \mathrm{pmol} / 10 \mathrm{ng}$ per side), or B: bilateral intra-vBNST pretreatment with $\mathrm{ICl}-118,551$ (1 nmol/277 $\mathrm{ng}$ per side) or vehicle on reinstatement in response to bilateral intra-vBNST CRF injection ( $63 \mathrm{pmol} / 300 \mathrm{ng}$ per side). Significant clenbuterol-induced reinstatement was observed in vehicle but not antalarmin pretreated rats ( ${ }^{*} p<0.05$ vs Ext). Responding following antalarmin was significantly reduced compared with vehicle pretreatment $\left({ }^{\#} p<0.05\right)$. By contrast, significant CRF-induced reinstatement was observed in both vehicle and ICl-118,551 pretreated rats ( ${ }^{*} p<0.05$ vs Ext) and did not significantly differ between the two pretreatment conditions.

norepinephrine-dependent effects in the vBNST has not been established, our finding that local antalarmin pretreatment blocks reinstatement by intra-vBNST clenbuterol delivery supports a role for local CRF actions in the regulation of cocaine seeking by norepinephrine and $\beta$-2 $\mathrm{AR}$ activation. Consistent with this possibility, previous studies demonstrated that (1) noradrenergic terminals synapse on the dendrites of CRF-positive neurons in the vBNST (Phelix et al., 1994), (2) $\beta$-2 AR-mediated reinstatement requires CRF-R1 activation (McReynolds et al., 2014 ), and (3) the $\beta$-2 AR antagonist, ICI118,551 , blocks stress-induced increases of BNST CRF mRNA (McReynolds et al., 2014). Overall, the findings are consistent with reports that cocaine seeking induced by central norepinephrine delivery is blocked by CRF receptor antagonism, whereas suppression of noradrenergic function using the $\alpha-2$ AR agonist, clonidine, does not affect reinstatement in response to central CRF delivery (Brown et al., 2009).

Notably, the magnitude of cocaine seeking in response to intra-vBNST clenbuterol was lower than that observed following either shock or CRF. This could be attributed to (1) secondary effects of BNST $\beta-2$ AR activation that are not engaged by shock or CRF and offset responding, (2) unique attributes of clenbuterol itself (e.g., pharmacokinetics, ligand-specific receptor desensitization), or (3) the requirement for additional stress-responsive mediators to fully engage the processes that lead to cocaine seeking.

Our findings suggest that the vBNST influences cocaine seeking via regulation of the VTA. Consistent with this possibility, stress-induced reinstatement in mice is associated with activation of VTAprojecting BNST neurons (Briand et al., 2010) and a role for a vBNST-VTA pathway in the expression of cocaine seeking has been reported (Sartor and AstonJones, 2012). In light of these findings, it is surprising that vBNST $\beta$-ARs have been found to exert inhibitory effects on neurons that project to the VTA, likely via

tion in the vBNST is necessary for shock-induced cocaine seeking and that intra-vBNST injection of a $\beta$-2 AR- but not a $\beta$-1 AR-selective agonist is sufficient to reinstate.

Beta-2 ARs are expressed throughout the BNST (Cecchi et al., 2007). Whereas in the dorsal BNST $\beta$ AR activation can have either excitatory or inhibitor effects on synaptic transmission, $\beta$ AR effects in the vBNST are predominantly inhibitory (Egli et al., 2005) and include inhibition of neurons that project directly to the VTA (Dumont and Williams, 2004). In the dorsal BNST, $\beta$-AR regulation of neuronal activity requires CRF-R1 activation (Nobis et al., 2011). Although the involvement of CRF in stimulation of local GABA release (Dumont and Williams, 2004). Both GABAergic and glutamatergic projections from the BNST to the VTA have been identified (Georges and Aston-Jones, 2001, 2002; Kudo et al., 2012; Jennings et al., 2013). Moreover, CRFpositive terminals within the VTA coexpress either the glutamatergic neuronal marker, vesicular glutamate transporter 2 , or the GABAergic neuronal marker, glutamic acid decarboxylase, and make contacts that have morphological characteristics of either excitatory or inhibitory synapses, suggesting that CRF can be coreleased into the VTA along with either GABA or glutamate (Tagliaferro and Morales, 2008). Further investigation is needed 
to (1) confirm the neurochemical phenotype of VTA-projecting vBNST CRF-positive neurons, (2) clarify the mechanism through which $\beta-2$ ARs regulate these neurons and determine how this regulation might change following cocaine exposure, and (3) examine the likelihood that $\beta$-2 AR in the vBNST may also regulate CRF and/or CRF actions in the VTA via parallel multisynaptic pathways. Consistent with the last possibility, BNST efferents can influence the VTA through multisynaptic pathways that include regions, such as the lateral habenula and rostromedial tegmental area (Dong and Swanson, 2006; Kaufling et al., 2009; Lammel et al., 2012).

It has been found that (1) shock elevates VTA CRF levels (Wang et al., 2005), (2) intra-VTA CRF delivery is sufficient to induce cocaine seeking (Wang et al., 2005; Blacktop et al., 2011), and (3) VTA CRF receptor activation is required for stressinduced reinstatement (Wang et al., 2005; Blacktop et al., 2011) in rats. Our demonstration that intra-VTA antalarmin delivery prevents shock-induced reinstatement is consistent with these reports. As the antalarmin dose used may also block CRF-R2 receptors, our findings are not definitive regarding which CRF receptor subtype is involved. However, we have reported that, in rats tested under identical conditions, intra-VTA delivery of a CRF-R2-selective antagonist does not prevent shock-induced reinstatement, whereas intra-VTA injection of a CRF-R1 but not a CRF-R2-selective agonist is sufficient to induce cocaine seeking (Blacktop et al., 2011).

CRF actions in the VTA are complex and involve both excitatory and inhibitory effects that vary depending on the receptor and site (Ungless et al., 2003; Riegel and Williams, 2008; Wanat et al., 2008; Beckstead et al., 2009; Hahn et al., 2009; Wanat et al., 2013). Likely VTA targets for CRF include mesocortical DA cells, which are activated during stress (Deutch et al., 1991). Elevated medial prefrontal cortex DA, via activation of DA receptors, is necessary for stress-induced reinstatement (Capriles et al., 2003; McFarland et al., 2004). We demonstrate that the mechanisms through which vBNST $\beta$-2 ARs regulate this CRF projection to the VTA requires local CRF actions, likely at CRF-R1. This finding is consistent with reports that (1) depolarization of BNST neurons by the nonselective $\beta$-AR agonist, isoproterenol, is CRFdependent (Nobis et al., 2011), (2) CRF in the BNST depolarizes neurons that project to the VTA (Silberman et al., 2013), and (3) stress-induced increases in CRF mRNA in the BNST in mice are $\beta$-2 AR-dependent (McReynolds et al., 2014). Moreover it is consistent with reports that intra-BNST antalarmin delivery prevents stress-induced cocaine seeking (Erb and Stewart, 1999; Erb et al., 2001). Although the requirement for vBNST CRF is evident, the source of this CRF has not been identified and could include intrinsic cell populations within the BNST and/or CRF-releasing projections originating in other regions (e.g., the central amygdala). A clearer mechanistic understanding awaits determination of BNST $\beta-2$ AR receptor localization as it relates to that of CRF and CRF-R1.

Although it is likely that the mechanisms through which stress promotes relapse are not identical across drug classes, both CRF-R1 receptor activation (Shaham et al., 1997; Lê et al., 2000; Bruijnzeel et al., 2009) and central noradrenergic signaling (Erb et al., 2000; Shaham et al., 2000; Lê et al., 2005; Yamada and Bruijnzeel, 2011) are necessary for stress-induced reinstatement of heroin-, nicotine-, and alcohol-seeking in rats. Moreover, in the case of heroin, stress-induced drug seeking requires CRF (Wang et al., 2006) and noradrenergic (Wang et al., 2001) signaling within the BNST. Notably, similar processes in the BNST may be engaged during withdrawal from ethanol (Francesconi et al.,
2009; Huang et al., 2010; Silberman et al., 2013) and opioids (Delfs et al., 2000; Fuentealba et al., 2000), suggesting that this pathway to the VTA, or parallel pathways originating in other BNST subregions may also contribute to withdrawal-related drug seeking.

To summarize, we report that, during stress, norepinephrine released into the vBNST activates $\beta$-2 ARs, which via a CRFdependent process, activate neurons that release CRF into the VTA, thereby leading to cocaine seeking. Identification of the processes responsible for stress-induced cocaine seeking should guide the development of new treatment approaches aimed at managing relapse, particularly in individuals whose use is stress-related.

\section{References}

Baker JG (2005) The selectivity of $\beta$-adrenoceptor antagonists at the human $\beta 1, \beta 2$ and $\beta 3$ adrenoceptors. Br J Pharmacol 144:317-322. CrossRef Medline

Baker JG (2010) The selectivity of $\beta$-adrenoceptor agonists at human $\beta 1$-, $\beta 2$ - and $\beta 3$-adrenoceptors. Br J Pharmacol 160:1048-1061. CrossRef Medline

Beckstead MJ, Gantz SC, Ford CP, Stenzel-Poore MP, Phillips PE, Mark GP, Williams JT (2009) CRF enhancement of GIRK channel-mediated transmission in dopamine neurons. Neuropsychopharmacology 34: 1926-1935. CrossRef Medline

Blacktop JM, Seubert C, Baker DA, Ferda N, Lee G, Graf EN, Mantsch JR (2011) Augmented cocaine seeking in response to stress or CRF delivered into the ventral tegmental area following long-access self-administration is mediated by CRF receptor type 1 but not CRF receptor type 2. J Neurosci 31:11396-11403. CrossRef Medline

Briand LA, Vassoler FM, Pierce RC, Valentino RJ, Blendy JA (2010) Ventral tegmental afferents in stress-induced reinstatement: the role of cAMP response element-binding protein. J Neurosci 30:16149-16159. CrossRef Medline

Brown ZJ, Tribe E, D'souza NA, Erb S (2009) Interaction between noradrenaline and corticotrophin-releasing factor in the reinstatement of cocaine seeking in the rat. Psychopharmacology 203:121-130. CrossRef Medline

Bruijnzeel AW, Prado M, Isaac S (2009) Corticotropin-releasing factor-1 receptor activation mediates nicotine withdrawal-induced deficit in brain reward function and stress-induced relapse. Biol Psychiatry 66:110-117. CrossRef Medline

Capriles N, Rodaros D, Sorge RE, Stewart J (2003) A role for the prefrontal cortex in stress- and cocaine-induced reinstatement of cocaine seeking in rats. Psychopharmacology 168:66-74. CrossRef Medline

Cecchi M, Capriles N, Watson SJ, Akil H (2007) $\beta 1$ Adrenergic receptors in the bed nucleus of stria terminalis mediate differential responses to opiate withdrawal. Neuropsychopharmacology 32:589-599. CrossRef Medline

Delfs JM, Zhu Y, Druhan JP, Aston-Jones G (2000) Noradrenaline in the ventral forebrain is critical for opiate withdrawal-induced aversion. Nature 403:430-434. CrossRef Medline

Deutch AY, Lee MC, Gillham MH, Cameron DA, Goldstein M, Iadarola MJ (1991) Stress selectively increases fos protein in dopamine neurons innervating the prefrontal cortex. Cereb Cortex 1:273-292. CrossRef Medline

Deyama S, Katayama T, Kondoh N, Nakagawa T, Kaneko S, Yamaguchi T, Yoshioka M, Minami M (2009) Role of enhanced noradrenergic transmission within the ventral bed nucleus of the stria terminalis in visceral pain-induced aversion in rats. Behav Brain Res 197:279-283. CrossRef Medline

Dong HW, Swanson LW (2006) Projections from bed nuclei of the stria terminalis, dorsomedial nucleus: implications for cerebral hemisphere integration of neuroendocrine, autonomic, and drinking responses. J Comp Neurol 494:75-107. CrossRef Medline

Dumont EC, Williams JT (2004) Noradrenaline triggers GABAA inhibition of bed nucleus of the stria terminalis neurons projecting to the ventral tegmental area. J Neurosci 24:8198-8204. CrossRef Medline

Egli RE, Kash TL, Choo K, Savchenko V, Matthews RT, Blakely RD, Winder DG (2005) Norepinephrine modulates glutamatergic transmission in the bed nucleus of the stria terminalis. Neuropsychopharmacology 30 : 657-668. CrossRef Medline 
Erb S, Stewart J (1999) A role for the bed nucleus of the stria terminalis, but not the amygdala, in the effects of corticotropin-releasing factor on stressinduced reinstatement of cocaine seeking. J Neurosci 19:RC35. Medline

Erb S, Hitchcott PK, Rajabi H, Mueller D, Shaham Y, Stewart J (2000) Alpha-2 adrenergic receptor agonists block stress-induced reinstatement of cocaine seeking. Neuropsychopharmacology 23:138-150. CrossRef Medline

Erb S, Salmaso N, Rodaros D, Stewart J (2001) A role for the CRFcontaining pathway from central nucleus of the amygdala to bed nucleus of the stria terminalis in the stress-induced reinstatement of cocaine seeking in rats. Psychopharmacology 158:360-365. CrossRef Medline

Fendt M, Siegl S, Steiniger-Brach B (2005) Noradrenaline transmission within the ventral bed nucleus of the stria terminalis is critical for fear behavior induced by trimethylthiazoline, a component of fox odor. J Neurosci 25:5998-6004. CrossRef Medline

Flavin SA, Winder DG (2013) Noradrenergic control of the bed nucleus of the stria terminalis in stress and reward. Neuropharmacology 70:324330. CrossRef Medline

Francesconi W, Berton F, Repunte-Canonigo V, Hagihara K, Thurbon D, Lekic D, Specio SE, Greenwell TN, Chen SA, Rice KC, Richardson HN, O’Dell LE, Zorrilla EP, Morales M, Koob GF, Sanna PP (2009) Protracted withdrawal from alcohol and drugs of abuse impairs long-term potentiation of intrinsic excitability in the juxtacapsular bed nucleus of the stria terminalis. J Neurosci 29:5389-5401. CrossRef Medline

Fuentealba JA, Forray MI, Gysling K (2000) Chronic morphine treatment and withdrawal increase extracellular levels of norepinephrine in the rat bed nucleus of the stria terminalis. J Neurochem 75:741-748. CrossRef Medline

Georges F, Aston-Jones G (2001) Potent regulation of midbrain dopamine neurons by the bed nucleus of the stria terminalis. J Neurosci 21:RC160. Medline

Georges F, Aston-Jones G (2002) Activation of ventral tegmental area cells by the bed nucleus of the stria terminalis: a novel excitatory amino acid input to midbrain dopamine neurons. J Neurosci 22:5173-5187. Medline

Graf EN, Hoks MA, Baumgardner J, Sierra J, Vranjkovic O, Bohr C, Baker DA, Mantsch JR (2011) Adrenal activity during repeated long-access cocaine selfadministration is required for later CRF-induced and CRF-dependent stressor-induced reinstatement in rats. Neuropsychopharmacology 36: 1444-1454. CrossRef Medline

Hahn J, Hopf FW, Bonci A (2009) Chronic cocaine enhances corticotropinreleasing factor-dependent potentiation of excitatory transmission in ventral tegmental area dopamine neurons. J Neurosci 29:6535-6544. CrossRef Medline

Huang MM, Overstreet DH, Knapp DJ, Angel R, Wills TA, Navarro M, Rivier J, Vale W, Breese GR (2010) Corticotropin-releasing factor (CRF) sensitization of ethanol withdrawal-induced anxiety-like behavior is brain site specific and mediated by CRF-1 receptors: relation to stress-induced sensitization. J Pharmacol Exp Ther 332:298-307. CrossRef Medline

Jennings JH, Sparta DR, Stamatakis AM, Ung RL, Pleil KE, Kash TL, Stuber GD (2013) Distinct extended amygdala circuits for divergent motivational states. Nature 496:224-228. CrossRef Medline

Jobes ML, Ghitza UE, Epstein DH, Phillips KA, Heishman SJ, Preston KL (2011) Clonidine blocks stress-induced craving in cocaine users. Psychopharmacology 218:83-88. CrossRef Medline

Kaufling J, Veinante P, Pawlowski SA, Freund-Mercier MJ, Barrot M (2009) Afferents to the GABAergic tail of the ventral tegmental area in the rat. J Comp Neurol 513:597-621. CrossRef Medline

Kudo T, Uchigashima M, Miyazaki T, Konno K, Yamasaki M, Yanagawa Y, Minami M, Watanabe M (2012) Three types of neurochemical projection from the bed nucleus of the stria terminalis to the ventral tegmental area in adult mice. J Neurosci 32:18035-18046. CrossRef Medline

LaLumiere RT, Niehoff KE, Kalivas PW (2010) The infralimbic cortex regulates the consolidation of extinction after cocaine self-administration. Learn Mem 17:168-175. CrossRef Medline

Lammel S, Lim BK, Ran C, Huang KW, Betley MJ, Tye KM, Deisseroth K, Malenka RC (2012) Input-specific control of reward and aversion in the ventral tegmental area. Nature 491:212-217. CrossRef Medline

Lê AD, Harding S, Juzytsch W, Watchus J, Shalev U, Shaham Y (2000) The role of corticotrophin-releasing factor in stress-induced relapse to alcohol-seeking behavior in rats. Psychopharmacol 150:317-324. CrossRef

Lê AD, Harding S, Juzytsch W, Funk D, Shaham Y (2005) Role of alpha-2 adrenoceptors in stress-induced reinstatement of alcohol seeking and alcohol self-administration in rats. Psychopharmacology 179:366-373. CrossRef Medline

Leri F, Flores J, Rodaros D, Stewart J (2002) Blockade of stress-induced but not cocaine-induced reinstatement by infusion of noradrenergic antagonists into the bed nucleus of the stria terminalis or the central nucleus of the amygdala. J Neurosci 22:5713-5718. Medline

Lowery-Gionta EG, Navarro M, Li C, Pleil KE, Rinker JA, Cox BR, Sprow GM, Kash TL, Thiele TE (2012) Corticotropin releasing factor signaling in the central amygdala is recruited during binge-like ethanol consumption in C57BL/6J mice. J Neurosci 32:3405-3413. CrossRef Medline

Mantsch JR, Weyer A, Vranjkovic O, Beyer CE, Baker DA, Caretta H (2010) Involvement of noradrenergic neurotransmission in the stress- but not cocaine-induced reinstatement of extinguished cocaine-induced conditioned place preference in mice: role for beta- 2 adrenergic receptors. Neuropsychopharmacology 35:2165-2178. CrossRef Medline

McFarland K, Davidge SB, Lapish CC, Kalivas PW (2004) Limbic and motor circuitry underlying footshock-induced reinstatement of cocaine-seeking behavior. J Neurosci 24:1551-1560. CrossRef Medline

McReynolds JR, Vranjkovic O, Thao M, Baker DA, Makky K, Lim Y, Mantsch JR (2014) Beta-2 adrenergic receptors mediate stress-evoked reinstatement of cocaine-induced conditioned place preference and increases in CRF mRNA in the bed nucleus of the stria terminalis in mice. Psychopharmacology (Berl). Advance online publication. Retrieved July 28, 2014. CrossRef Medline

Nobis WP, Kash TL, Silberman Y, Winder DG (2011) $\beta$-Adrenergic receptors enhance excitatory transmission in the bed nucleus of the stria terminalis through a corticotrophin-releasing factor receptor-dependent and cocaine-regulated mechanism. Biol Psychiatry 69:1083-1090. CrossRef Medline

Onaka T, Yagi K (1998) Role of noradrenergic projections to the bed nucleus of the stria terminalis in neuroendocrine and behavioral responses to fear-related stimuli in rats. Brain Res 788:287-293. CrossRef Medline

Pacak K, McCarty R, Palkovits M, Kopin IJ, Goldstein DS (1995) Effects of immobilization on in vivo release of norepinephrine in the bed nucleus of the stria terminalis in conscious rats. Brain Res 688:242-246. CrossRef Medline

Park J, Wheeler RA, Fontillas K, Keithley RB, Carelli RM, Wightman RM (2012) Catecholamines in the bed nucleus of the stria terminalis reciprocally respond to reward and aversion. Biol Psychiatry 71:327-334. CrossRef Medline

Paxinos G, Watson C (2006) The rat brain in stereotaxic coordinates, Ed 6 . San Diego: Academic.

Phelix CF, Liposits Z, Paull WK (1992) Monoamine innervation of bed nucleus of stria terminalis: an electron microscopic investigation. Brain Res Bull 28:949-965. CrossRef Medline

Phelix CF, Liposits Z, Paull WK (1994) Catecholamine-CRF synaptic interaction in a septal bed nucleus: afferents of neurons in the bed nucleus of the stria terminalis. Brain Res Bull 33:109-119. CrossRef Medline

Phillipson OT (1979) Afferent projections to the ventral tegmental area of Tsai and interfascicular nucleus: a horseradish peroxidase study in the rat. J Comp Neurol 187:117-143. CrossRef Medline

Ricardo JA, Koh ET (1978) Anatomical evidence of direct projections from the nucleus of the solitary tract to the hypothalamus, amygdala, and other forebrain structures in the rat. Brain Res 153:1-26. Medline

Riegel AC, Williams JT (2008) CRF facilitates calcium release from intracellular stores in midbrain dopamine neurons. Neuron 57:559-570. CrossRef Medline

Rodaros D, Caruana DA, Amir S, Stewart J (2007) Corticotropin-releasing factor projections from limbic forebrain and paraventricular nucleus of the hypothalamus to the region of the ventral tegmental area. Neuroscience 150:8-13. CrossRef Medline

Roozendaal B, Schelling G, McGaugh JL (2008) Corticotropin-releasing factor in the basolateral amygdala enhances memory consolidation via an interaction with the $\beta$-adrenoceptor-cAMP pathway: dependence on glucocorticoid receptor activation. J Neurosci 28:6642-6651. CrossRef Medline

Sakanaka M, Shibasaki T, Lederis K (1986) Distribution and efferent projections of corticotropin-releasing factor-like immunoreactivity in the rat amygdaloid complex. Brain Res 382:213-238. CrossRef Medline

Sartor GC, Aston-Jones G (2012) Regulation of the ventral tegmental area 
by the bed nucleus of the stria terminalis is required for expression of cocaine preference. Eur J Neurosci 36:3549-3558. CrossRef Medline

Shaham Y, Funk D, Erb S, Brown TJ, Walker CD, Stewart J (1997) Corticotropin-releasing factor, but not corticosterone, is involved in stressinduced relapse to heroin-seeking in rats. J Neurosci 17:2605-2614. Medline

Shaham Y, Highfield D, Delfs J, Leung S, Stewart J (2000) Clonidine blocks stress-induced reinstatement of heroin seeking in rats: an effect independent of locus coeruleus noradrenergic neurons. Eur J Neurosci 12:292302. CrossRef Medline

Silberman Y, Matthews RT, Winder DG (2013) A corticotropin releasing factor pathway for ethanol regulation of the ventral tegmental area in the bed nucleus of the stria terminalis. J Neurosci 33:950-960. CrossRef Medline

Stamatakis AM, Sparta DR, Jennings JH, McElligott ZA, Decot H, Stuber GD (2014) Amygdala and bed nucleus of the stria terminalis circuitry: implications for addiction-related behaviors. Neuropharmacology 76:320328. CrossRef Medline

Tagliaferro P, Morales M (2008) Synapses between corticotropin-releasing factor-containing axon terminals and dopaminergic neurons in the ventral tegmental area are predominantly glutamatergic. J Comp Neurol 506: 616-626. CrossRef Medline

Ungless MA, Singh V, Crowder TL, Yaka R, Ron D, Bonci A (2003) Corticotropin-releasing factor requires $\mathrm{CRF}$ binding protein to potentiate NMDA receptors via CRF receptor 2 in dopamine neurons. Neuron 39: 401-407. CrossRef Medline

Vranjkovic O, Hang S, Baker DA, Mantsch JR (2012) $\beta$-Adrenergic receptor mediation of stress-induced reinstatement of extinguished cocaineinduced conditioned place preference in mice: roles for $\beta 1$ and $\beta 2$ adrenergic receptors. J Pharmacol Exp Ther 342:541-551. CrossRef Medline

Wanat MJ, Hopf FW, Stuber GD, Phillips PE, Bonci A (2008) Corticotropin-releasing factor increases mouse ventral tegmental area dopamine neuron firing through a protein kinase C-dependent enhancement of Ih. J Physiol 586:2157-2170. CrossRef Medline

Wanat MJ, Bonci A, Phillips PE (2013) CRF acts in the midbrain to attenu- ate accumbens dopamine release to rewards but not their predictors. Nat Neurosci 16:383-385. CrossRef Medline

Wang B, Shaham Y, Zitzman D, Azari S, Wise RA, You ZB (2005) Cocaine experience establishes control of midbrain glutamate and dopamine by corticotropin-releasing factor: a role in stress-induced relapse to drug seeking. J Neurosci 25:5389-5396. CrossRef Medline

Wang J, Fang Q, Liu Z, Lu L (2006) Region-specific effects of brain corticotropin-releasing factor receptor type 1 blockade on footshockstress- or drug-priming-induced reinstatement of morphine conditioned place preference in rats. Psychopharmacology 185:19-28. CrossRef Medline

Wang X, Cen X, Lu L (2001) Noradrenaline in the bed nucleus of the stria terminalis is critical for stress-induced reactivation of morphineconditioned place preference in rats. Eur J Pharmacol 432:153-161. CrossRef Medline

Webster EL, Lewis DB, Torpy DJ, Zachman EK, Rice KC, Chrousos GP (1996) In vivo and in vitro characterization of antalarmin, a nonpeptide corticotropin-releasing hormone $(\mathrm{CRH})$ receptor antagonist: suppression of pituitary ACTH release and peripheral inflammation. Endocrinology 137:5747-5750. CrossRef Medline

Weller KL, Smith DA (1982) Afferent connections to the bed nucleus of the stria terminalis. Brain Res 232:255-270. CrossRef Medline

Woulfe JM, Hrycyshyn AW, Flumerfelt BA (1988) Collateral axonal projections from the A1 noradrenergic cell group to the paraventricular nucleus and bed nucleus of the stria terminalis in the rat. Exp Neurol 102:121-124. CrossRef Medline

Woulfe JM, Flumerfelt BA, Hrycyshyn AW (1990) Efferent connections of the Al noradrenergic cell group: a DBH immunohistochemical and PHA-L anterograde tracing study. Exp Neurol 109:308-322. CrossRef Medline

Yamada H, Bruijnzeel AW (2011) Stimulation of $\alpha 2$-adrenergic receptors in the central nucleus of the amygdala attenuates stress-induced reinstatement of nicotine seeking in rats. Neuropharmacology 60:303-311. CrossRef Medline 